\title{
Environmental Protection in the European Union
}

Volume 5

Series Editors

Michael Schmidt, Brandenburg University of Technology Cottbus-Senftenberg, Cottbus, Germany

Lothar Knopp, Brandenburg University of Technology Cottbus-Senftenberg, Germany 


\title{
Environmental Protection in the European Union
}

\author{
Volume 1 \\ M. Schmidt, L. Knopp \\ Reform in CEE-Countries with Regard \\ to European Enlargement \\ 2004, XII, 205 pages \\ ISBN 978-3-540-40259-6
}

\section{Volume 2}

M. Schmidt, E. João, E. Albrecht

Implementing Strategic

Environmental Assessment

2005, XXXII, 742 pages

ISBN 978-3-540-20562-3

\section{Volume 3}

M. Schmidt et al.

Standards and Thresholds

for Impact Assessment

2008, XXIX, 493 pages

ISBN 978-3-540-31140-9

Volume 4

E. Albrecht et al.

Implementing Adaptation Strategies by Legal,

Economic and Planning Instruments on Climate Change

2014, XVI, 356 pages

ISBN 978-3-540-77613-0 
Yumiko Nakanishi

Editor

\section{Contemporary Issues in Environmental Law}

The EU and Japan

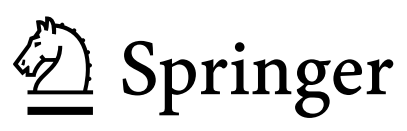




\author{
Editor \\ Yumiko Nakanishi \\ Kunitachi, Tokyo \\ Japan
}

ISSN 1613-8694

Environmental Protection in the European Union

ISBN 978-4-431-55434-9 ISBN 978-4-431-55435-6 (eBook)

DOI 10.1007/978-4-431-55435-6

Library of Congress Control Number: 2015960202

\title{
Springer Tokyo Heidelberg New York Dordrecht London \\ (C) Springer Japan 2016
}

This work is subject to copyright. All rights are reserved by the Publisher, whether the whole or part of the material is concerned, specifically the rights of translation, reprinting, reuse of illustrations, recitation, broadcasting, reproduction on microfilms or in any other physical way, and transmission or information storage and retrieval, electronic adaptation, computer software, or by similar or dissimilar methodology now known or hereafter developed.

The use of general descriptive names, registered names, trademarks, service marks, etc. in this publication does not imply, even in the absence of a specific statement, that such names are exempt from the relevant protective laws and regulations and therefore free for general use.

The publisher, the authors and the editors are safe to assume that the advice and information in this book are believed to be true and accurate at the date of publication. Neither the publisher nor the authors or the editors give a warranty, express or implied, with respect to the material contained herein or for any errors or omissions that may have been made.

Printed on acid-free paper

Springer Japan KK is part of Springer Science+Business Media (www.springer.com) 
For Prof. Dr. Yoshio Otani 



\section{Preface}

The EU Studies Institute in Tokyo (EUSI Tokyo) is a consortium of Hitotsubashi University, Keio University, and Tsuda College. It is sponsored by the European Union and promotes academic education, research, and activities engendering public knowledge of the EU in Japan. It aims at strengthening the relations between Japan and the EU. As outreach and academic activities, the EUSI has held symposiums, workshops, and seminars. The EUSI laws focused on environmental issues from 2013 to 2015 . We had EUSI symposiums titled 'Contemporary Issues in EU Environmental Law: Part I' on 28 October 2014 and 'Contemporary Issues in EU Environmental Law: Part II' on 21 April 2015. In addition, we held an EUSI workshop titled 'Principles of EU Environmental Law: An Appraisal' on 30 October 2014. We have also regularly held research seminars on environmental law. This book is based on the results presented at these research gatherings.

This book presents a variety of articles on contemporary issues in environmental law by eminent university professors of environmental law, international public law, European Union law, and comparative law in Europe and Japan. It is the first book in the field of environmental law based on the results of international conferences and research activities supported by the European Union delegation in Japan.

Current essential and global topics such as principles of environmental law, climate change, biodiversity, ethics pertaining to animal rights, nuclear safety regime after Fukushima, environmental impact assessments, protecting international waters, genetically-modified organisms, and implementing international instruments, and EU rules at the national level are discussed in light of the 2009 Treaty of Lisbon and other recent international treaties, by comparing the approaches taken by the EU, European countries, and Japan.

As environmental law is not just a national issue but also a global one, it is important to understand and analyse various aspects of current environmental 
issues. This book is a response to such needs, and represents the joint work of six Japanese and four European (two German and two Italian) professors who have succeeded in creating something that is both unique and remarkable.

Tokyo, Japan

Yumiko Nakanishi 


\section{Contents}

1 Introduction: The Impact of the International and European Union Environmental Law on Japanese Basic Environmental Law . . . . . . . . . . . . . . . . . . . . . . . . . . . . . . . Yumiko Nakanishi

2 The Scope of the EU's Competences on the Field of the Environment.

Alexander Proelss

3 Principles of EU Environmental Law: An Appraisal . . . . . . . . . 29 Alexander Proelss

4 The Aarhus Convention and Cases of Non-compliance with Environmental Impact Assessment Requirements: The EU and Japan

Yuko Minami

5 Policies Towards Tackling Climate Change and Their Compatibility with the WTO Kiyotaka Morita

6 The Principle of Animal Welfare in the EU and Its Influence in Japan and the World Yumiko Nakanishi

7 Protecting Biodiversity in Europe: The Habitats and Birds Directives and Their Application in Italy in an Evolving Perspective ............................. 115 Sara De Vido

8 The Challenge of Regulating Genetically Modified Organisms in the European Union: Trends and Issues . . . . . . . . . . . . . . . . 139 Hans-Georg Dederer 
9 The Proliferation of Marine Protected Areas Under International Law, European Union Law and Japanese Law . . . . . . . . . . . . . 169 Chie Sato

10 Environmental Damage Remediation in Japan: A Comparative Assessment . .

Andrea Ortolani

11 Challenges and Prospects for the Nuclear Safety Regime in Japan and in the European Union After Fukushima . . . . . . . . . . . . . . 199 Kyoji Kawasaki and Ryoko Kusumi

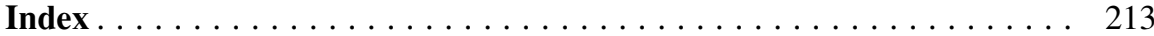




\section{Contributors}

\section{Editor}

Yumiko Nakanishi, professor of European Union law at Graduate School of Law, Hitotsubashi University, Tokyo Japan (since April 2012). Director of the EU Studies Institute in Tokyo (EUSI), member of the board of directors of the European Union Studies Association-Japan, representative of the Hitotsubashi Association of European Union Law, member of Japan Association of Environmental Law and Policy, member of Japanese Society of International Law, member of the Japanese Association of World Law, member of Forschungsgesellschaft für deutsches Verfassungsrecht, Japan. Her fields of research are competence issues in the EU, EU constitutional law, EU environmental law and EU external relations law. 1987-1991 Osaka University, 1991 bachelor of arts, 1991-2000 legal studies at Universities of Hitotsubashi and Münster, Germany. 1993 master of law (Hitotsubashi University); 1995 master of law, 1998 doctor of law (University of Münster). 2000-2002 lecturer, 2002-2008 associate professor, 2008-2012 professor of European Union law (Senshu Univeristy, Tokyo). Her publications include the following. Books: Collection of case law analysis regarding EU competences, Shinzansha, Tokyo, 2015 (in Japanese); Legal structure of EU competences, Shinzansha, Tokyo, 2013 (in Japanese); European Union law, Shinseisha, Tokyo, 2012 (in Japanese); Die Entwicklung der Außenkompetenzen der Europäischen Gemeinschaft, Peter Lang, Frankfurt am Main, 1998 (in German). Articles in books: Legal measures toward Euro zone crisis, in E Ogawa (ed) The Euro zone crisis and the world economy, University of Tokyo Press, 2015, pp 69-106; Development of political principles in external action of the EU, in N Yasue (ed) The EU and global governance, Horitsubunkasha, Kyoto, 2013, pp 69-100; Directive 2004/35/EC on environmental liability as means of implementation of EU environmental law, in H Nagano and A Okamatsu (eds) Environment and law, Sanwashobo, Tokyo, 2010 (in Japanese), pp 91-121; Principle of environmental integration in the EU, in K Shoji (ed) EU environmental law, Keio University Press, Tokyo, pp 115-150 (in Japanese); CSR and human rights in the EU, in T Matsumono and Y Sugiura (eds) Corporate social responsibility, Keiso Shobo, 2007, pp 149-177 (in Japanese). Articles in Journals: Development of EU exclusive competences for the conservation of marine biological resources. The Hitotsubashi Journal of Law and International Studies 13(2), 2014, pp 53-91 (in Japanese); Political principles in Article 21 TEU and constitutionalism. Hitotsubashi Journal of Law and Politics 42, 2014, pp 11-23; EU competence of external relations. EU Studies in Japan (31), 2011, pp127-147 (in Japanese); Development of the competences of the EU. The Journal of International Law and Diplomacy 108(3), 2009, pp 31(349)-60(378) (in Japanese); Federalismus reform in Germany and the EU. Senshu Hogaku Ronshu (100), 2007, pp 173-210 (in Japanese); Withdrawal clause in the treaty establishing a constitution for Europe. The Journal 
of International Law and Diplomacy 103(4), 2005, pp 33(565)-60(592) (in Japanese); The scope of the EU's competence in the field of environment. Senshu Hogaku Ronshu (106), 2009, pp 81116 (in Japanese); Environmental protection according to the article 176 of the treaty of the EC. Senshu Hogaku Ronshu (97), 2006, pp 83-127 (in Japanese); Charter of fundamental rights in the draft treaty. Journal of World Affairs 51(10), 2003, pp 38-52 (in Japanese); Duty of the consistent interpretation by the European Court of Justice. Senshu Hogaku Ronshu (85), 2002, pp 1-42 (in Japanese); Research for preliminary ruling of the EU (bimonthly series). Jichikenkyu September 2009-(in Japanese).

\section{Authors}

Hans-Georg Dederer, professor of public law, University of Passau, Germany. He studied law in Tuebingen and Konstanz from 1988 to1992. After his legal internship from 1992 to 1995 in Konstanz and Washington, D.C., he was, first, lecturer and, subsequently, reader at the University of Bonn. In 1998, he received his doctorate in law (Bonn) and in 2003 his Habilitation (Bonn). Since 2009, he is professor of constitutional and administrative law, public international law, European and international economic law at the University of Passau. His fields of research include constitutional law (human dignity, property, judicial review), biotechnology law (agrobiotechnology, embryo protection, stem cell research) and public international law (world trade law, foreign investment law, environmental law). His publications include the following. Monographs: (e.g., Korporative Staatsgewalt, Tübingen, 2004; Adventitious presence of GMOs in seed, Heidelberg, 2001 (with M. Herdegen as co-author); Gentechnikrecht im Wettbewerb der Systeme, 1998. Articles in law journals: (e.g., Die Grenzen des Vorrangs des Unionsrechts. Juristenzeitung 2014, pp 313-322; Die Garantie der Menschenwürde (Art. 1 Abs. 1 GG). Jahrbuch des öffentlichen Rechts 2009, pp 89-124; Regulation of human embryonic stem cell research in Germany. Journal of International Biotechnology Law 3, 2006, pp 63-71. Contributions in handbooks, encyclopedias, proceedings etc. (e.g., Extraterritorial possibilities of enforcement in cases of human rights violations, in M Bungenberg and S Hobe (eds) Permanent sovereignty over natural resources. Cham, 2015, pp 187-216; 'Responsibility to Protect' and 'Functional Sovereignty', in P Hilpold (ed) Responsibility to Protect $(R 2 P) — A$ new paradigm in international law? Leiden, 2015, pp 156-183; Genetic technology and food security, in M Schmidt-Kessel (ed) German national reports on the 19th International Congress for Comparative Law, Tübingen, 2014, pp 303-354; Grenzübergreifender Umweltschutz, in J Isensee and P Kirchhof (eds) Handbuch des Staatsrechts, 3rd ed., Vol. XI, § 248, Heidelberg, 2013, 55 p; The common commercial policy under the influence of commission, council, high representative, and European external action service, in M Bungenberg and C Herrmann (eds) Common commercial policy after Lisbon, 2013, pp 87-105; Enemy property, in R Wolfrum (ed) Max Planck Encyclopedia of Public.

Kyoji Kawasaki, professor of international public law, dean of the School of International and Public Policy, Hitotsubashi University, fields of specialization: international law. He received an LLB and an LLM from Hitotsubashi University, Japan. He was a visiting researcher at University of Pisa, Italy (1993-1994) and University of Paris II, France (2004-2005). His major publications in English include the following: Introductory statement: Japanese experience in nuclear liability compensation after Fukushima incident, in C Raetzke (ed) Nuclear law in the EU and beyond. Nomos, 2014, pp 327-331; Accountability of the United Nations from the perspective of international law, in Kuyama and Fowler (eds) Envisioning reform: enhancing UN accountability in the twenty-first century, United Nations University Press, 2009, pp 116-132; International jus cogens in the law of state responsibility, in C Focarelli (ed) Le nuove frontiere del diritto internazionale, Morlacchi Editore, Perugia, 2008, pp 145-165; A brief note on the legal effects of jus cogens in 
international law. Hitotsubashi Journal of Law \& Politics 34, 2006, pp 27-43; State responsibility and terrorist activities, in A de Guttry (ed) Oltre la reazione: Complessità e limiti nella guerra al terrorismo internazionale dopo I'11 settembre, Edizioni ETS, Pisa, 2003, pp 65-81; The "injured state" in the international law of state responsibility. Hitotsubashi Journal of Law \& Politics 28, 2000, pp17-31.

Ryoko Kusumi, doctoral candidate, international law, graduate school of law, received an LLB and an LLM from Hitotsubashi University, Japan. She was safety officer/consultant of International Atomic Energy Agency, Austria (2005-2007, 2013-2015) and secretary general of European Nuclear Education Network, France (2007-2013). Her major publications include the following: Current status and challenges of the nuclear safety convention. Risk Management in Public Policy, 2011, pp187-208; Recent developments in the non-proliferation of nuclear weapons-safeguards by International Atomic Energy Agency. ISYP Journal of Science and World Affairs 1(2) 2005, pp 87-102; The amended Convention on the Physical Protection of Nuclear Material (CPPNM). IAEA Department of Nuclear Safety and Security newsletter, January 2005-September 2005 (18), 2005, p. 5. Co-author, Security trade control-practice and issues in Japan. International Security 32 (2), 2004, pp 1-30. Master's dissertation, International Atomic Energy Agency-Activities and their original characters. Hitotsubashi University, 2004; Diploma of International Nuclear Law, Is the NPT still an effective instrument to prevent the proliferation of nuclear weapons? Montpellier University, 2003.

Yuko Minami, associate professor, Department of International and Cultural Studies, Tsuda College. LLB (Hitotsubashi University of Tokyo) 1993, LLM 1995. Previous position held at the Miyazaki Municipal University. Since 2000, full-time lecturer of international law at Tsuda College. Recent publications include the following: MOX kojo jiken: Kankyo osen no boshi to kokusai saiban (Mox Plant case: Prevention of environmental pollution and international court). Kankyo Kanri (Environmental management) 45(5), 2009, pp 59-65.

Kiyotaka Morita, senior manager, Keidanren (Japan Business Federation) visiting professor, Hitotsubashi University School of International and Public Policy. He joined Keidanren (Japan Business Federation) in 1997. From 2001 to 2003, he was seconded to permanent mission of Japan to the international organizations in Geneva as advisor where he was in charge of WTO negotiations on trade in services. On returning to Keidanren, he has been assigned to several posts including chief administrator of Environmental Policy Bureau where he dealt with negotiations under the United Nations Framework Convention on Climate Change (UNFCCC) and manager of international cooperation bureau responsible for economic partnership agreements (including China-Japan-Korea FTA, TPP and RCEP), infrastructure development, international labour policy and regional affairs (Asia, Africa and Americas). He was promoted to senior manager in 2015. As visiting professor of Hitotsubashi University School of International and Public Policy, he focuses mainly on international economic law. His publications include the following: International economic law under WTO, Kokusai Shoin, 2010 (in Japanese) Legal aspects of the emissions trading scheme based on "Cap and Trade." Hitotsubashi Journal of Law and Politics 43, 2015. He holds B.A. (1995) and M.A. (1997) from Hitotsubashi University Faculty of Law.

Andrea Ortolani, assistant professor of comparative law, Keio University, Tokyo, Japan. He graduated in law in Torino (Italy) with a dissertation on legal translation and earned his Ph.D. in private comparative law at the University of Trento (Italy), with a dissertation on the circulation of the Western legal models in Japan. He currently lives in Tokyo and majors in comparative law, with a particular interest towards Japanese law. He wrote, among other topics, on the Japanese criminal jury (the saiban'in seido), on environmental damage in Japan, and on the various influences of foreign scholarship on Japanese law and legal scholarship. He currently teaches comparative law and EU law at Hitotsubashi University. 


\begin{abstract}
Alexander Proelss, professor for public law, in particular public international law and European law, at Trier University, Germany (since October 2010). Dean of the Department of Law, director of the Institute of Environmental and Technology Law (IUTR), member of the board of directors of the Centre for European Studies of Trier University. 1995-2000 legal studies at the Universities of Bonn and Tübingen (2000 First State Examination in Law). 2003 doctor of laws, University of Tübingen. 2002-2004 legal clerkship (2004 bar exam). 2010 postdoctoral qualification (Habilitation/venia legendi) for public law, public international law and European law, faculty of law, University of Tübingen. 2004-2006 assistant professor in public law and public international law, University of Tübingen (affiliated to the chair of professor Wolfgang Graf Vitzthum). 2005-2006 research fellow at the federal constitutional court of Germany (Bundesverfassungsgericht) (affiliated to the department of Justice Udo Di Fabio). 2007-2010 full professor for public law, University of Kiel director of the Walther Schücking Institute for International Law member of the Kiel Excellence Cluster "The Future Ocean."
\end{abstract}

Chie Sato, lecturer for European Union law and public international law, at Meiji University, School of Law, Japan (since April 2011). 1993-1998 legal study at Hitotsubashi University, Japan. 1999 LLM, Graduate School of Law, Philipps-Universität Marburg, Germany. 2000 LLM, Graduate School of Law, Hitotsubashi University. 2003 doctor of laws, Philipps-Universität Marburg, Germany. 2004-2007 research adviser for international law/law of the sea, Ministry of Foreign Affairs, Economic Affairs Bureau, Ocean Division, working at Consulate General of Japan at Hamburg. 2007-2008 officer, Ministry of Foreign Affairs, Treaty Division. 2009-2011 research fellow at support project for Strategic University Collaborations, Hitotsubashi University.

Sara De Vido, assistant professor of international law at Ca' Foscari University, Venice, Italy, where she teaches international law, EU law, international business law. She holds a $\mathrm{PhD}$ in international law (University of Padua, Italy). She was one of the participants in the Englishspeaking section of the Centre for Studies and Research, the Hague Academy of International Law, in 2013. In October 2014 she spent a period of research at Kobe University and Hitotsubashi University (Tokyo, Japan). She has been confirmed as academic visitor/ research collaborator at Manchester University (UK) for autumn 2015. She has been recently appointed as vice-director of the Centre for Human Rights (Cestudir), at Ca' Foscari. Her main research interests include human rights issues (combating violence against women, right to water, prohibition of genocide), international environmental law, and the fight against transnational criminality (terrorist financing, money laundering, corruption). 